\title{
Hydrogen Evolution from Alcohols, Malate and Mixed Electron Donors by Rhodopseudomonas sp. No. 7
}

\author{
Takaaki FuJII, Masaaki TARUSAWA, Masaki MiYANAGA, \\ Seiichiro KiYota, Tetsuro Watanabe \\ and Minoru YABUKI \\ Department of Agricultural Chemistry, Chiba University, \\ Matsudo 648, Matsudo-shi, Chiba 271, Japan
}

Received March 3, 1986

\begin{abstract}
The hydrogen evolution from ethanol, $n$-propanol, $n$-butanol, malate and mixed substrates containing these compounds by Rhodopseudomonas sp. No. 7 was examined. A small amount of bicarbonate was necessary for the commencement of the hydrogen evolution in an alcoholglutamate medium by the bacterium grown in an alcohol- $\mathrm{NH}_{4}^{+}$medium. Bicarbonate added to the medium was a concentration of less than one-tenth of that required for the maximum growth in the alcohol- $\mathrm{NH}_{4}^{+}$medium. Once the cells had acquired the ability of hydrogen evolution, they continued to evolve hydrogen regardless of the presence or absence of bicarbonate. The rate and the yield of the evolution were improved in a medium containing both an alcohol and malate. These substrates were not preferentially but simultaneously consumed in the mixed medium. The alcohols and malate were effective for the evolution when the electron donors were used at low concentrations and when the incubation temperature was elevated to $40^{\circ} \mathrm{C}$, respectively. The yield and the rate of the evolution at $40^{\circ} \mathrm{C}$ were $70 \%$ and $80 \mu \mathrm{l} / \mathrm{mg}$ cell $/ \mathrm{hr}$, respectively. The bacterium incubated in a medium containing an alcohol exhibited a higher level of glutamine synthetase than that in the malate-medium.
\end{abstract}

Light-dependent evolution of molecular hydrogen has been recognized as a general property of photosynthetic purple non-sulfur bacteria since it was observed in a culture of Rhodospirillum rubrum by Gest and Kamen. ${ }^{1)}$ These bacteria require an appropriate organic compound as an electron donor for the hydrogen evolution because they do not have the ability of water photolysis. Organic acids, such as malic acid and lactic acid, have been mostly used as electron donors so far. ${ }^{2 \sim 12)}$ Alcohols seem to be more excellent electron donors than organic acids considering their chemical structures, but information on the hydrogen evolution from alcohols is limited. ${ }^{2,12)}$ Furthermore, little is known about the evolution from mixed electron donors of clearly known compositions. We isolated a strain of the genus Rhodopseudomonas capable of producing hydrogen from alcohols. ${ }^{12)}$ The growth rate of the bacterium was promoted by using mixed electron donors consisting of an alcohol and malate. ${ }^{13)}$ The bacterium consumed these compounds simultaneously. Pike and Sojka ${ }^{14)}$ reported that Rhodopseudomonas sphaeroides showed diauxic growth on a malate-glycerol medium. In contrast, Rhodopseudomonas sp. No. 7 did not show diauxic growth on a malate-alcohol medium.

This report deals with the hydrogen evolution by Rhodopseudomonas sp. No. 7 from alcohols, malate and mixed substrates containing these compounds.

\section{MATERIALS AND METHODS}

Organ̈ism, media and growth conditions. Rhodopseudomonas sp. No. 7 and its maintenance were described previously. ${ }^{12,15)}$ The basal salt medium containing $0.1 \%$ electron donor and $0.1 \%$ nitrogen source was used for the main culture. Ethanol, $n$-propanol, $n$-butanol or L-malate was used as an electron donor and $\mathrm{NH}_{4} \mathrm{Cl}$ or L-glutamate as a nitrogen source. In the case of the 
alcohol-containing media, $0.2 \%$ sodium bicarbonate was added. The organism was grown at $30^{\circ} \mathrm{C}$ in screw-capped 1.5 liter Roux bottles filled with a medium. These bottles were illuminated at an intensity of 5000 lux with $60 \mathrm{~W}$ incandescent lamps.

Hydrogen evolution assay. Hydrogen evolution was assayed by the standard method described previously. ${ }^{12}$

Enzyme assays. Cell-free extracts were prepared as described previously. ${ }^{12)}$ Glutamine synthetase activity was determined by the $\gamma$-glutamyl transferase assay method of Shapiro and Stadtman. ${ }^{16)}$ Glutamate synthase activity was assayed as described by Alef et al. ${ }^{17)}$ Glutamate dehydrogenase was assayed by the method of Bchofen and Neeracher. ${ }^{18)}$ Nitrogenase activity was examined using washed cells. The activity was assayed by the method of Miyake et al. ${ }^{11)}$

Protein. Protein was determined by the Lowry method using bovine serum albumin as a standard. ${ }^{19)}$

Other assays. Alcohols were estimated by gas chromatography. The column material was Porapak Q (80 to $100 \mathrm{mesh}, 3 \mathrm{~mm} \times 100 \mathrm{~cm}$ ). The column temperature was $175^{\circ} \mathrm{C}$. The carrier gas, nitrogen, was used at a flow rate of $30 \mathrm{ml} / \mathrm{min}$. The concentrations of L-malate and Lglutamate were determined by the methods of Möllering ${ }^{20)}$ and Sorwerby and Ottaway, ${ }^{211}$ respectively, using $F$-kits from Boehringer Mannheim.

\section{RESULTS}

\section{Effect of sodium bicarbonate on hydrogen evo-} lution from alcoho's

It was reported that Rhodopseudomonas sp. No. 7 could evolve hydrogen from alcohols in the absence of sodium bicarbonate. ${ }^{12)}$ But the hydrogen evolution was not always stable. Therefore, further examination of the effect of bicarbonate was conducted with cells grown in an alcohol-medium containing ammonium chloride or glutamate as a nitrogen source. When $0.1 \% n$-propanol and ammonium chloride were used as the carbon and electron source and nitrogen source, respectively, the maximum yield of growth was attained in the medium containing $0.2 \%$ bicarbonate. No growth occurred in the absence of bicarbonate. Therefore, cells were transferred to the hydrogen evolving medium after they had been precultivated in the presence of $0.2 \%$ bicarbonate in all cases. Figure 1 shows

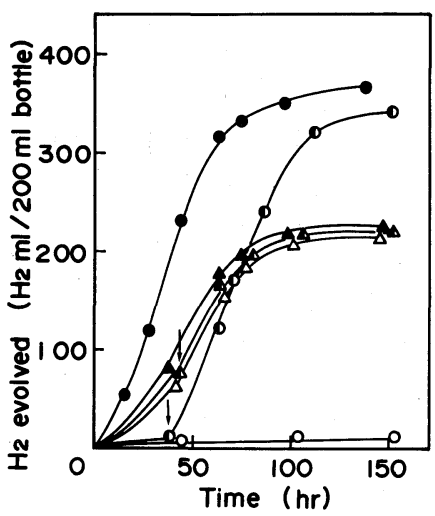

FIG. 1. Effect of Sodium Bicarbonate on Hydrogen Evolution from $n$-Propanol by Rhodopseudomonas sp. No. 7.

Cells were grown in the basal medium containing $0.1 \% n$ propanol as an electron source and $0.1 \% \mathrm{NH}_{4} \mathrm{Cl}(\bullet, \odot$, $\bigcirc)$ or glutamate $(\boldsymbol{\Delta}, \Delta, \triangle)$ as a nitrogen source in the presence of $0.2 \%$ sodium bicarbonate, harvested in the exponential growth phase and then incubated in the hydrogen evolving medium containing $n$-propanol and glutamate with $(\boldsymbol{O}, \boldsymbol{\Delta})$ or without $(O, \triangle)$ bicarbonate. Bicarbonate was also added to some incubation bottles $(\boldsymbol{D}, \Delta)$ at the times indicated by arrows after $42 \mathrm{hr}$ incubation.

that cells grown in a medium containing glutamate as a nitrogen source could evolve hydrogen from $n$-propanol regardless of the presence or absence of bicarbonate in the hydrogen evolving medium. On the other hand, cells grown in the medium containing ammonium chloride as a nitrogen source could evolve hydrogen in the presence of bicarbonate but not in its absence. In the latter case, hydrogen began to evolve on the addition of a small amount of bicarbonate to the incubation mixture, that is, about one-tenth the amount required for the maximum growth in the preculture. Further addition of bicarbonate did not promote the hydrogen evolution. Similar results were obtained in the case of hydrogen evolution from ethanol or $n$ butanol.

The nitrogenase activity in cells evolving hydrogen was about $0.4 \sim 1.2 \mu \mathrm{mol} / \mathrm{mg}$ dry cell wt./min. But when cells grown on ammonium chloride were transferred to the hydrogen evolving medium without bicarbonate, no ac- 
tivity was detected in the cells notwithstanding the derepressed conditions for nitrogenase formation. In these cells, nitrogenase was formed on the addition of a small amount of bicarbonate to the incubation mixture. Therefore, when alcohols were used as electron donors, only incubation of cells under nitrogenase derepresed conditions was not enough for the hydrogen evolution.

\section{Effect of the concentration of an electron donor on the hydrogen evolution}

Figure 2 shows the hydrogen evolution from ethanol, $n$-propanol and malate at various concentrations. Cells were incubated with the same kinds of electron donors as those used for the precultures. When cells grown on $0.1 \%$
$(21.7 \mathrm{~mm})$ ethanol or $0.1 \%(16.6 \mathrm{~mm}) n$ propanol were transferred to the hydrogen evolving medium containing an alcohol at concentrations from $0.02 \%$ to $0.1 \%$, the amount of hydrogen evolved was almost proportional to the concentration. But when alcohols were added at concentrations of more than $0.2 \%$, the hydrogen evolution was inhibited and stopped at about $0.6 \%$. In contrast to in the case of alcohols, only a small amount of hydrogen was evolved from malate when it was added to the incubation mixture at concentrations of less than $0.1 \%(7.4 \mathrm{~mm})$. The maximum rate of hydrogen evolution from malate was obtained on the addition of $0.3 \%$ to $0.6 \%$. But the maximum rate was lower than that with $0.1 \%$ alcohols. Furthermore, in the

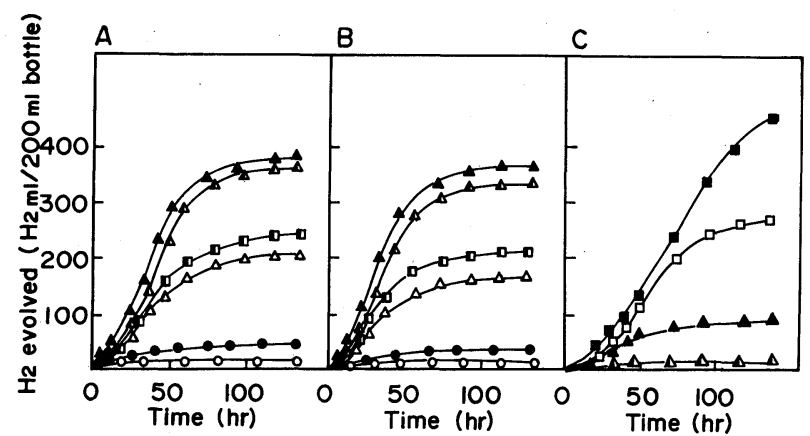

FIG. 2. Effect of the Concentration of Electron Donors on Hydrogen Evolution by Rhodopseudomonas sp. No. 7.

Electron donors were added to incubation bottles at the initial concentrations of $0.01 \%(\bigcirc), 0.02 \%$ $0.05 \%(\triangle), 0.1 \%(\triangle), 0.2 \%(\Delta), 0.3 \%(\square), 0.4 \%(\square)$ or $0.6 \%(\square)$. A, ethanol was used as an electron donor; $\mathrm{B}, n$-propanol; C, malate.

Table I. Effect of Electron Donors in the Preculture on Hydrogen Evolution

Cells were grown in the basal medium containing the indicated electron donors at $0.1 \%$ concentration for $48 \sim 72 \mathrm{hr}$. The harvested cells were incubated in the hydrogen evolving medium containing $0.1 \%$ electron donors. The total evolved hydrogen was determined by the standard method.

\begin{tabular}{|c|c|c|c|c|c|}
\hline \multirow{2}{*}{$\begin{array}{l}\text { Electron donor } \\
\text { for growth }\end{array}$} & \multicolumn{5}{|c|}{$\begin{array}{l}\text { Evolution of hydrogen from } \\
\left(\mathrm{H}_{2} \mathrm{ml} / 200 \mathrm{ml} \text { bottle }\right)\end{array}$} \\
\hline & Ethanol & $n$-Propanol & $n$-Butanol & L-Malate & L-Lactate \\
\hline Ethanol & 310 & 257 & 188 & 85 & 94 \\
\hline$n$-Propanol & 336 & 375 & 269 & 49 & 55 \\
\hline$n$-Butanol & 244 & 162 & 165 & 44 & 25 \\
\hline L-Malate & 288 & ND & ND & ND & ND \\
\hline L-Lactate & 318 & ND & ND & ND & ND \\
\hline
\end{tabular}

ND, not detectable. 
malate medium a longer lag time for the hydrogen evolution was observed.

The ability of hydrogen evolution of cells grown on various organic compounds

The hydrogen evolution from alcohols and organic acids was examined using cells grown on these compounds, respectively (Table I). They were added to the media at $0.1 \%$. Cells grown on malate or lactate did not evolve hydrogen from $0.1 \%$ electron donors other than ethanol. On the other hand, cells grown on alcohols could evolve hydrogen from all electron donors tested.

\section{Evolution of hydrogen from mixed electron donors}

a) Mixture of an alcohol and malate. Figure 3 shows the hydrogen evolution from mixed electron donors composed of $0.1 \%(16.6 \mathrm{~mm})$ $n$-propanol and $0.1 \%(7.4 \mathrm{~mm})$ malate by cells grown on $n$-propanol. Cells began to consume these compounds immediately after initiation of the incubation. The course of the hydrogen evolution did not show diauxic behavior. The rate of evolution from mixed electron donors was higher than that from the individual components. Furthermore, it was found that the total hydrogen evolved from mixed donors was more than the sum of the quantities from the individual substrates. Although the con-

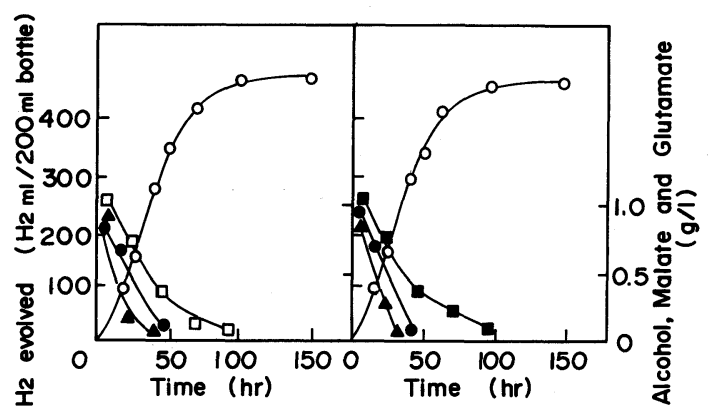

Fig. 3. Time Course of Hydrogen Evolution from Mixed Electron Donors Consisting of Alcohols and Malate by Rhodopseudomonas sp. No. 7.

An alcohol (ethanol or $n$-propanol) and malate were mixed at the concentration of $0.1 \%$.

Total evolved hydrogen $(\bigcirc)$; consumption of glutamate

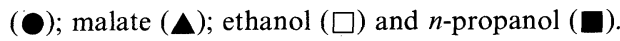

sumption of $n$-propanol was slower than that of malate, it seemed that the gap between the rates of consumption was caused by the addition of alcohol and malate at the same concentrations by weight but not by molarity. Similar results were obtained in the case of mixing ethanol and malate. No bicarbonate was required for the evolution from mixed electron donors containing an alcohol and malate.

The yields of hydrogen evolution were determined by comparing the amount of hydrogen evolved with the theoretical values. The theoretical values were calculated using the following equations.

Ethanol

$$
\begin{aligned}
& \mathrm{C}_{2} \mathrm{H}_{5} \mathrm{OH}+3 \mathrm{H}_{2} \mathrm{O}=2 \mathrm{CO}_{2}+6 \mathrm{H}_{2} \\
& n \text {-Propanol }
\end{aligned}
$$

$$
\mathrm{C}_{3} \mathrm{H}_{7} \mathrm{OH}+5 \mathrm{H}_{2} \mathrm{O}=3 \mathrm{CO}_{2}+9 \mathrm{H}_{2}
$$

Malic acid

$$
\mathrm{C}_{4} \mathrm{H}_{6} \mathrm{O}_{5}+3 \mathrm{H}_{2} \mathrm{O}=4 \mathrm{CO}_{2}+6 \mathrm{H}_{2}
$$

Glutamic acid

$$
\mathrm{C}_{5} \mathrm{H}_{9} \mathrm{NO}_{4}+6 \mathrm{H}_{2} \mathrm{O}=5 \mathrm{CO}_{2}+9 \mathrm{H}_{2}+\mathrm{NH}_{3}
$$

The conversion yields for mixed electron donors composed of alcohols and malate were higher than those for donors incubated individually. The yields for ethanol, $n$-propanol, malate, ethanol-malate and $n$-propanol-malate were $45,36,14,48$ and $48 \%$, respectively. In all cases, the cell concentration increased during the incubation. Usually the dry weight of the bacterium increased $c a .0 .43 \mathrm{~g}$ for every $1 \mathrm{~g}$ of substrate (sum of glutamate, malate and ethanol). A similar result was obtained with the medium containing glutamate, malate and $n$-propanol. These results indicate that the bacterium can efficiently convert substrates to hydrogen and cell materials.

b) Mixture of two kinds of alcohols. The hydrogen evolution in a mixed system consisting of two kinds of alcohols was examined. Methanol, ethanol, $n$-propanol and $n$-butanol was used as electron donors. Figure 4 shows 


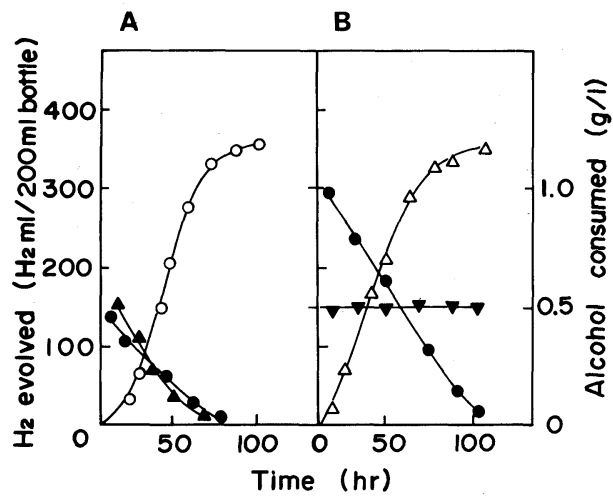

FIG. 4. Hydrogen Evolution from Mixed Electron Donors Consisting of Two Kinds of Alcohols.

(A) The hydrogen evolution from the $0.05 \%$ ethanol$0.05 \%$-propanol system $(O)$ and the consumption of ethanol (O) and $n$-propanol $(\boldsymbol{\Delta})$.

(B) The hydrogen evolution from the $0.05 \%$ methanol$0.1 \%$ ethanol system $(\triangle)$ and the consumption of methanol ( $\mathbf{\nabla})$ and ethanol (O).

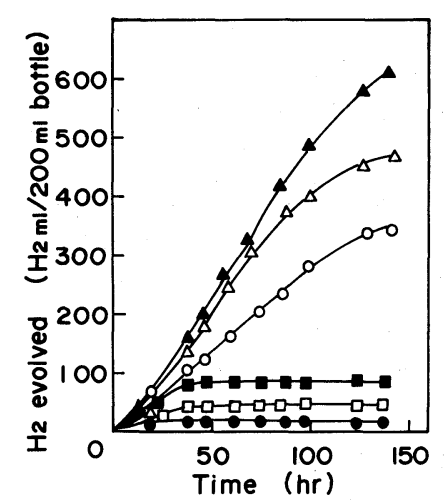

FIG. 5. Effect of Temperature on Hydrogen Evolution.

The hydrogen evolution was assayed by the standard method except that the temperature was varied. Some bottles were incubated at $40^{\circ} \mathrm{C}$ (closed symbols) and control bottles at $30^{\circ} \mathrm{C}$ (open symbols). The electron donors used were as follows: $n$-propanol, $(\boldsymbol{O}, \bigcirc)$; malate,

$(\square, \square)$; malate- $n$-propanol, $(\mathbf{\Lambda}, \triangle)$.

the evolution from an ethanol- $n$-propanol system and a ethanol-methanol system, respectively. Practically, almost equal amounts of hydrogen were evolved from all incubation mixtures tested except for systems containing methanol. Alcohols in mixed systems were consumed simultaneously during the incubation, however, the rate of hydrogen evolution was not stimulated, unlike that in the
Table II. Activities of Glutamate Synthase and Glutamine Synthetase In Rhodopseúdomonas sp.

No. 7 Incubated in Hydrogren Evolving Media

Cells grown in the $0.1 \% n$-propanol medium were then incubated in hydrogen evolving media for $96 \mathrm{hr}$.

\begin{tabular}{|c|c|c|c|}
\hline \multirow{2}{*}{$\begin{array}{l}\text { Hydrogen } \\
\text { donor }\end{array}$} & \multicolumn{2}{|c|}{$\begin{array}{c}\text { Enzyme activity } \\
(\mathrm{nmol} / \mathrm{min} / \mathrm{mg} \text { protein })\end{array}$} & \multirow{2}{*}{$\begin{array}{c}\text { Total } \\
\text { evolved- } \\
\text { hydrogen } \\
\text { (ml/200 ml } \\
\text { bottle) }\end{array}$} \\
\hline & $\begin{array}{l}\text { Glutamate } \\
\text { synthase }\end{array}$ & $\begin{array}{l}\text { Glutamine } \\
\text { synthetase }\end{array}$ & \\
\hline \multicolumn{4}{|l|}{ n-Propanol } \\
\hline+ malate & 5.17 & 477 & 471 \\
\hline \multicolumn{4}{|l|}{ Ethanol } \\
\hline+ malate & 5.96 & 447 & 462 \\
\hline$n$-Propanol & 7.53 & 354 & 311 \\
\hline Ethanol & 6.58 & 419 & 353 \\
\hline Malate & 6.06 & 207 & 55 \\
\hline $\begin{array}{l}n \text {-Propanol } \\
\quad\left(-\mathrm{NaHCO}_{3}\right)\end{array}$ & 5.50 & 87 & ND \\
\hline
\end{tabular}

ND, not detectable.

case of the malate-alcohol mixed systems. On the other hand, methanol was not consumed even when mixed together with any one of ethanol, $n$-propanol and $n$-butanol. But it did not inhibit the evolution of hydrogen from other alcohols.

c) Effect of temperature on hydrogen evolution. Figure 5 shows the hydrogen evolution from $n$-propanol, malate and mixed substrates consisting of these compounds at $40^{\circ} \mathrm{C}$. The rate and the yield of the evolution from mixed substrates were higher at $40^{\circ} \mathrm{C}$ than those at $30^{\circ} \mathrm{C}$. The maximum evolution rate was $80 \mu \mathrm{l} / \mathrm{mg}$ cell wt. $/ \mathrm{hr}$ and the yield was over $70 \%$ of the theoretical value at $40^{\circ} \mathrm{C}$. But the evolution from individual alcohols added alone to the medium stopped at this temperature. No hydrogen evolution was observed at $45^{\circ} \mathrm{C}$. Similar results were obtained in the case of the hydrogen evolution from the mixture of ethanol and malate.

Activities of glutamine synthetase and glutamate synthase in cells evolving hydrogen

Table II shows the activities of glutamine synthetase and glutamate synthase in cells incubated in hydrogen evolving media containing an alcohol and/or malate. There was 
no significant difference in glutamate synthase activity among all cells tested. On the other hand, with regard to glutamine synthetase, cells which showed high ability of hydrogen evolution had a tendency to exhibit high enzyme activity. The highest activity was found in cells incubated in the mixed systems composed of an alcohol and malate. The activity in cells incubated in a medium containing only an alcohol in the absence of sodium bicarbonate was considerably low. These cells could not evolve hydrogen as described above. No glutamate dehydrogenase was detected in any of the cells tested.

\section{DISCUSSION}

Alcohols seem to be the excellent hydrogen donors for purple non-sulfur bacteria judging from their chemical structures. Under anaerobic light conditions, these bacteria usually consume excess reductant generated from an alcohol for fixation of carbon dioxide. ${ }^{22)}$ This report indicates that Rhodopseudomonas sp. No. 7 characteristically evolves hydrogen from short straight chain alcohols other than methanol. Namely, the bacterium evolved hydrogen most effectively from alcohols among the electron donors tested, and the cells preincubated with an alcohol became capable of evolving hydrogen from organic acids at low concentrations. Furthermore, it was found that the rate and the yield of the hydrogen evolution were improved by using a medium containing both an alcohol and malate. In this case, the two substrates are simultaneously consumed. Strain No. 7 possesses a constitutive NAD-linked alcohol dehydrogenase. ${ }^{12)}$ This seems to account for the simultaneous consumption of substrates. But it is not enough to explain the hydrogen evolution from a medium containing an alcohol.

As described above, purple non-sulfur bacteria can not metabolize alcohols in the absence of suitable electron acceptors, such as bicarbonate, under anaerobic light conditions. In the previous paper, it was reported that strain No. 7 could grow in an alcohol- containing medium without bicarbonate when it was evolving hydrogen. ${ }^{12)}$ In addition to this, it was indicated that a small amount of bicarbonate is necessary for the stable commencement of the hydrogen evolution from an alcohol when cells have been transferred from a nitrogenase-repressed medium to a derepresed medium (a hydrogen evolution medium). If bicarbonate or an other suitable carbon dioxide source is absenct from the evolution medium, nitrogenase activity is not always observed in these cells. The activity of glutamine synthetase also does not increase. But when once the cells have been incubated with an alcohol in the presence of a small amount of bicarbonate, they synthesize nitrogenase, and become capable of evolving hydrogen from the alcohol, of maintaining the oxidation reduction balance in cells by discharging excess reductant from the alcohol as hydrogen and of growing in an alcoholcontaining medium regardless of the presence or absence of bicarbonate. At this time, the level of glutamine synthetase in cells has increased to more than two times compared with that in cells incubated with an organic acid. It has been reported that glutamine synthetase might play a role as an effector of the nitrogenase gene and regulate the level of nitrogenase activity in cells. ${ }^{23 \sim 30)}$ Although the direct relationship between glutamine synthetase and alcohols must be further investigated, it is suggested that the increase in the level of glutamine synthetase in cells caused by an alcohol promotes the synthesis of nitrogehase and consequently the evolution of hydrogen from the alcohol is enhanced.

Besides, it has been reported that alcohols affect the lipid composition of the cellmembrane, ${ }^{31)}$ therefore, it is suggested that alcohols may alter the activity of a membranefixed enzyme, nitrogenase, or the permeability of the cell membrane for substrates and hydrogen.

Acknowledgments. This work was supported in part by Grants-in-Aid from the Special Coordinating Funds for Promoting Science and Technology of the Science and Technology Agency of Japan. We wish to thank Dr. 
Kawamura, Dr. Miyake and Mr. Asada of the Fermentation Research Institute for the helpful comments and discussions.

\section{REFERENCES}

1) H. Gest and M. D. Kamen, Science, 109, 558 (1949).

2) I. N. Gogotov, T. V. Mitkina and V. P. Glinskii, Mikrobiologiya (in English), 43, 495 (1974).

3) P. Hillmer and H. Gest, J. Bacteriol., 129, 724 (1977).

4) P. Hillmer and H. Gest, J. Bacteriol., 129, 732 (1977).

5) B. A. Macler, R. A Pelroy and J. A Bassham, J. Bacteriol., 138, 446 (1979).

6) J. S. Kim, K. Ito and H. Takahashi. Agric. Biol. Chem., 44, 827 (1980).

7) K. Watanabe, J. S. Kim, K. Ito, L. Buranakarl, T. Kampel and H. Takahashi, Agric. Biol. Chem., 45, 217 (1981).

8) J. S. Kim, K. Ito and H. Takahashi, J. Ferment. Technol., 59, 185 (1981).

9) J. S. Kim, H. Yamauchi, K. Ito and H. Takahashi, Agric. Biol. Chem., 46, 1469 (1982).

10) J. Miyake, N. Tomizuka and S. Kawamura, Report of the Fermentation Research Institute, Japan, No. 58, 25 (1982).

11) J. Miyake, N. Tomizuka and A. Kamibayashi, J. Ferment. Technol., 60, 199 (1982).

12) T. Fujii, A. Nakazawa, N. Sumi, H. Tani, A Ando and M. Yabuki, Agric. Biol. Chem., 47, 2747 (1983).

13) T. Fujii, M. Taruzawa, M. Miyanaga, A. Ando and M. Yabuki, Hakkokogaku., 64, 71 (1985).

14) L. Pike and G. A. Sojka, J. Bacteriol., 124, 1101 (1975).

15) T. Fujii, Y. Honda, A. Ando and M. Yabuki, Agric. Biol. Chem., 46, 2209 (1982).

16) B. Shapiro and E. R. Stadtman, "Methods in
Enzymolgy," Vol. XVIIA, ed. by H. Tabor and C. W. Tabor, Academic Press Inc., New York, 1970, p. 910.

17) K. Alef, H. J. Burkardt, H. J. Horstman and W. G. Zumft, Z. Naturforsch., 36, 246 (1981).

18) R. Bchofen and H. Neeracher, Arch. Mikrobiol., 60, 235 (1968).

19) O. H. Lowry, N. J. Rosebrough, A. L. Farr and R. J. Randall, J. Biol. Chem., 193, 265 (1951).

20) H. Möllering, "Methods of Enzymatic Analysis," Vol. 3, ed. by H. U. Bergmeyer, Academic Press Inc., New York and London, 1974, p. 1589.

21) J. Sorwerby and J. H. Ottaway, Biochem. J., 79, $21 \mathrm{p}$ (1961).

22) G. A. Sojka, "The Photosynthetic Bacteria," ed. by R. K. Clayton and W. R. Sistrom, Plenum Press, New York, 1978, pp. 707 716.

23) B. C. Johansson and H. Gest, Eur. J. Biochem., 81, 365 (1977).

24) J. D. Wall and H. Gest, J. Bacteriol., 137, 1459 (1979).

25) P. Hillmer and K. Fahlbusch, Arch. Microbiol., 122, 213 (1979).

26) D. C. Yoch and M. Cantu, J. Bacteriol., 142, 899 (1980).

27) K. Alef, D. J. Arp and W. G Zumft, Arch. Microbiol., 130, 138 (1981).

28) G. Falk, B. C. Johansson and S. Nordlund, Arch. Microbiol., 132, 251 (1982).

29) H. Engelhardt and J. H. Klemme, Arch. Microbiol., 133, 202 (1982).

30) Y. Jouanneau, S. Lebecque and P. M. Vignais, Arch. Microbiol., 139, 326 (1984).

31) L. O. Ingram and T. M. Buttke, Advan. Microbiol. Physiol., 25, 254 (1984). 